DOI: https://doi.org/10.32839/2304-5809/2020-12-88-23

УДК 657.3

Бутко Н.В., Погрібняк В.В.

Черкаський національний університет імені Богдана Хмельницького

\title{
ОРГАНІЗАЦІЯ ОБЛІКУ ДЕБІТОРСЬКОЇ ЗАБОРГОВАНОСТІ В УПРАВЛІННІ ПІДПРИСМСТВОМ
}

Анотація. У статті досліджено теоретико-методичні основи обліку дебіторської заборгованості згідно П(С) БО 10 «Дебіторська заборгованість». Розглянуто підходи до змістовного наповнення поняття дебіторська заборгованість. Висвітлено класифікаційні ознаки дебіторської заборгованості у межах суб'ектів підприємництва. Особливу увагу приділено питанням організації обліку дебіторської заборгованості в системі управління підприемством. Розглянуто основні етапи організації обліку дебіторської заборгованості на підприємстві. Узагальнено наслідки недосконалості організації обліку дебіторської заборгованості суб’ектів підприємництва та виокремлено актуальні проблеми його ведення. Виявлено доцільність створення підприемствами резерву сумнівних боргів з метою відображення реальної суми поточної дебіторської заборгованості.

Ключові слова: дебітор, підприемство, організація обліку, дебіторська заборгованість, класифікація, резерв сумнівних боргів.

Butko Nataliia, Pohribniak Viktoriia

Bohdan Khmelnytsky National University of Cherkasy

\section{ORGANIZATION OF DEBTORS MANAGEMENT IN BUSINESS ADMINISTRATION}

Summary. The article examines the methodological aspects of debtors management of the enterprise in accordance with The Accounting standard 10 «Accounts receivable». Approaches to the details of the concept of «debtors management» are considered. The following characteristics of accounts receivable within the enterprise are taken into account: duration, quality composition, term of fulfillment of obligations, the possibility of control, expediency of formation, nature of the organization's activities, degree of risk, depending on the statute of limitations, types of debtors. Special attention is paid to the organization of debtors management in business administration the enterprise management. Recommendations for improving accounting in accordance with the peculiarities of activities of objects in business are outlined. The organization of debtors management in business administration is shown as a package of measures related to the application of accounting procedures. It allows to form information correctly, and to provide timely information getting about receivables of subjects of economic activity. Such information within debtors management regarding its size and maturity dates is taken to interested external and internal users. Besides the organization of debtors management ensures control over the financial state and the result of the enterprise activity. The main steps of the organization of debtors management at the enterprise are considered. The accounting process of debtors management within the enterprise is presented as a technological set of three stages: stage of primary accounting, stage of current accounting, and stage of final accounting. The consequences of imperfect organization of debtors management of economic agents are summed up in the article. The topical problems of accounting as follows imperfect selection of potential buyers and customers, inadequate work with contracts, accounting for the reserve of doubtful debts. The expediency of creating a reserve on doubtful debts at enterprises in order to show the real sum of the floating debt is revealed.

Keywords: debtor, enterprise, accounting organization, debtors management, classification, reserve on doubtful debts.

$\Pi^{2}$ остановка проблеми. Протягом виробничого циклу кожне підприемство здійснюе господарські операції з іншими суб’ектами підприемництва задля найшвидшої реалізаціі своєї продукції, за рахунок розширення ринків збуту та збільшення обсягів продажу. Однак нині розповсюдженою ситуацією є реалізація товарів контрагентам на умовах наступної оплати, тобто в кредит, в результаті чого і виникае дебіторська заборгованість. Тому існування дебіторської заборгованості є об'єктивним і звичним явищем в процесі виробничо-господарської діяльності суб'ектів підприемництва, проте повинно постійно контролюватися з метою своєчасного погашення.

Зі збільшенням обсягу дебіторської заборгованості в активах суб’ектів підприемництва, уповільнюеться оборотність грошових коштів, що зумовлюе необхідність залучення додаткових джерел фінансування. Тому в сучасних умовах господарювання уникнути появи дебіторської заборгованості, незалежно від причин її виникнен- ня, неможливо. Звідси важливим аспектом для забезпечення ефективної і стабільної діяльності окремого підприемства, $є$ необхідність у покращені організації обліку дебіторської заборгованості, який дозволить вирішити питання оптимізащії та забезпеченості своєчасного повернення грошових коштів, мінімізації обсягів заборгованості та неплатоспроможності відповідного суб'єкта підприемництва.

Аналіз останніх досліджень і публікацій. Теоретичні та практичні аспекти організації обліку дебіторської заборгованості досліджували вітчизняні та зарубіжні вчені-економісти, зокрема Г.М. Бескота, В.С. Белозерцев, Є. Брікхем, Ф.Ф. Бутинець, Л.М. Васільева, А.Ю. Волостникова, Є.В. Дубровська, Г.Г. Кірейщев, М.Л. Котляр, В.С. Лень, О.Г. Лищенко, Г.В. Нашкерська, О.О. Сидоренко, В.В. Сопко, С. Хенк, К. Хувер та ін.

Виділення не вирішених раніше частин загальної проблеми. В умовах сьогодення недостатній рівень знань щодо причин ведення 
та організащії обліку дебіторської заборгованості призводить до погіршення фрінансово-економічного стану суб'єкта підприемництва та його роботи в цілому. Ці фрактори зазначили потребу в необхідності додаткового вивчення, систематизації та уточнення організації обліку дебіторської заборгованості в управлінні підприемством.

Мета статті. Головною метою ціеї роботи є висвітлення теоретичних, практичних та проблемних аспектів щодо обліку розрахунків 3 дебіторами із врахування особливостей обліку операщій 3 коригування резерву сумнівних боргів в сучасних умовах господарювання.

Виклад основного матеріалу. У процесі своеї виробничої діяльності підприемство постійно вступає у господарські відносини 3 різноманітними суб'єктами підприємництва, що супроводжуеться потребою у здійсненні розрахунків 3 ними. Здійснюючи відвантаження виробленої продукції чи виконання робіт та надання послуг, підприемство прагне відразу повернути вкладені кошти і отримати дохід. Однак нині, у зв'язку із нестабільністю ринкової ситуації та спадом виробництва, постачальники не отримують оплату від контрагентів у визначені терміни, відбуваеться їх кредитування. Тому протягом періоду неплатежів, фінансові ресурси суб'єкта підприемництва виступають у вигляді дебіторської заборгованості.

Нині трактуванню поняття «дебіторська заборгованість» присвячені не лише велика кількість наукових робіт вчених-економістів, кожен 3 яких дає йому своє визначення (рис. 1), а також і нормативні акти, серед яких основним $є$ Положення (стандарт) бухгалтерського обліку (далі П(С)БО) 10 «Дебіторська заборгованість». Згідно якого, дебіторська заборгованість - це сума заборгованості дебіторів (юридичних та фрізичних осіб) підприємству на певну дату [1]. Проте, з огляду на розглянуті джерела, які розкривають змістовне наповнення поняття «дебіторська заборгованість» щодо формування единого підходу до його сутності, так і не досягнуло єдності серед поглядів вчених-економістів.

Для ефрективного управління і організації обліку дебіторською заборгованістю постає необхідність економічно правильно здійснювати класифрікацію відповідних об'єктів, від якої залежить і сам порядок обліку на підприемстві, рис. 2. 3 огляду на це, необхідно забезпечити якісне і своєчасне відображення інформації про заборгованість у системі бухгалтерського обліку.

Основи класифрікації дебіторської заборгованості посідають важливе місце в едективній організації обліку суб'єкта підприемництва. Відповідно до чинного законодавства підприємство самостійно може обирати систему класифрікації дебіторської заборгованості залежно від завдань і мети управління системою обліку в межах підприємства. Поділ за класифрікаційними ознаками дебіторської заборгованості надае можливість визначити обсяги майбутніх економічних вигод за відвантаження виробленої продукції чи виконання робіт та надання послуг, раціонально планувати фрінансові ресурси підприємства, виявити порушення розрахунків з дебіторами та успішно здійснювати управління роботою підприемства в цілому.

Під організацією бухгалтерського обліку дебіторської заборгованості розуміють сукупність дій, пов'язаних із застосуванням облікових процедур, які дають можливість правильно сфрормувати і забезпечити своєчасне отримання повної, достовірної, правдивої інформації про дебіторську заборгованість підприемства щодо їі розмірів та термінів погашення защікавленим зовнішнім і внутрішнім користувачам та здійснювати контроль за величиною їі впливу на фінансовий стан та результат діяльності підприемства.

\begin{tabular}{|c|}
\hline $\begin{array}{l}\text { неоплачені } \text { юридичними та } \\
\text { особами } \text { послуги } 3 \text { транспортування } \\
\text { вантажів та/або вилучені кошти } 3 \\
\text { кругообігу підприємства, що мають } \\
\text { документальне підтвердження, яке надає } \\
\text { право на отримання боргу в вигляді } \\
\text { грошових коштів, їх еквівалентів або інших } \\
\text { активів }\end{array}$ \\
\hline
\end{tabular}

\begin{tabular}{|l|}
\hline \multicolumn{2}{l}{ складова оборотного } \\
капіталу, яка є комплексом \\
вимог до фізичних чи \\
юридичних осіб щодо \\
оплати товарів, продукції, \\
послуг
\end{tabular}

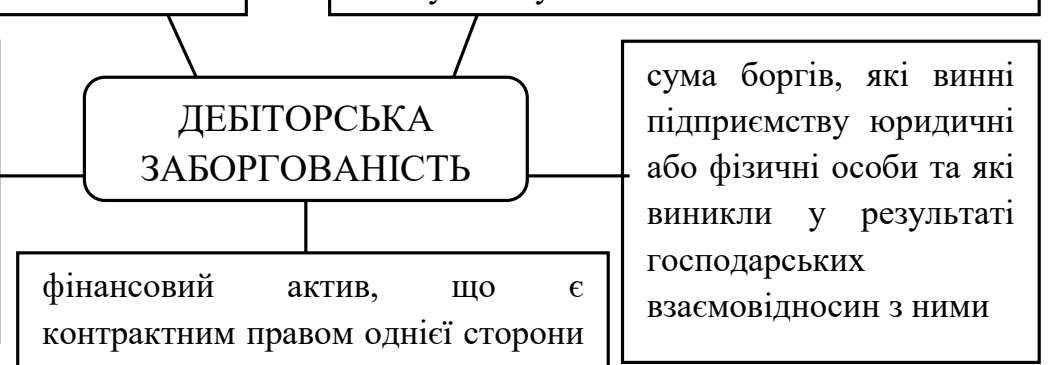

отримати гроші й узгоджується 3 відповідним зобов'язанням сплати іншої сторони

грошове вираження результату вимушеної або заздалегідь запланованої господарськоекономічної операції кредитного характеру 3 контрагентами, що мала місце у минулому та борг за неї може бути достовірно визначений, узгоджений 3 контрагентом та сплачений підприємству у майбутньому 


\begin{tabular}{|c|c|}
\hline \multicolumn{2}{|c|}{ КЛАСИФІКАЦІЯ ДЕБІТОРСЬКОЇ ЗАБОРГОВАНОСТІ } \\
\hline \multirow{2}{*}{$\begin{array}{r}\text { За тривалістю: } \\
\text { - довгострокова; } \\
\text { - короткострокова. }\end{array}$} & \multirow{3}{*}{$\begin{array}{c}\text { За характером } \\
\text { діяльності організації: } \\
\text { - за основною діяльністю; } \\
\text { - за фінансовою діяльністю; } \\
\text { - за інвестиційною діяльністю. }\end{array}$} \\
\hline & \\
\hline \multirow{2}{*}{$\begin{aligned} & \text { За якісним складом: } \\
& \text { - нереальна для стягнення; } \\
& \text { - сумнівна; } \\
& \text { - надійна. }\end{aligned}$} & \\
\hline & \multirow{2}{*}{$\begin{array}{l}\text { За ступенем ризику: } \\
\text { - } 3 \text { високим ризиком; } \\
\text { - } 3 \text { середнім ризиком; } \\
\text { - } 3 \text { низьким ризиком. }\end{array}$} \\
\hline \multirow{2}{*}{$\begin{array}{l}\text { За терміном виконання } \\
\text { зобов'язань: } \\
\text { - поточна; } \\
\text { - прострочена. }\end{array}$} & \\
\hline & \multirow{2}{*}{$\begin{array}{l}\text { Залежно від строків } \\
\text { позовної давності: } \\
\text { - прострочена; } \\
\text { - непрострочена. }\end{array}$} \\
\hline \multirow{2}{*}{$\begin{array}{l}\text { За можливістю контролю: } \\
\text { - контрольована; } \\
\text { - неконтрольована. }\end{array}$} & \\
\hline & \multirow{3}{*}{$\begin{array}{l}\quad \text { За видами дебіторів: } \\
\text { - покупців і замовників; } \\
\text { - дочірніх організацій; } \\
\text { - працівників організаціі; } \\
\text { - бюджету і позабюджетних } \\
\text { фондів. }\end{array}$} \\
\hline За доцільністю утворення: & \\
\hline $\begin{array}{l}\text { - виправдана; } \\
\text { - невиправдана. }\end{array}$ & \\
\hline
\end{tabular}

Рис. 2. Основні класифікаційні ознаки дебіторської заборгованості

Джерело: згруповано авторами за даними [7, с. 45]

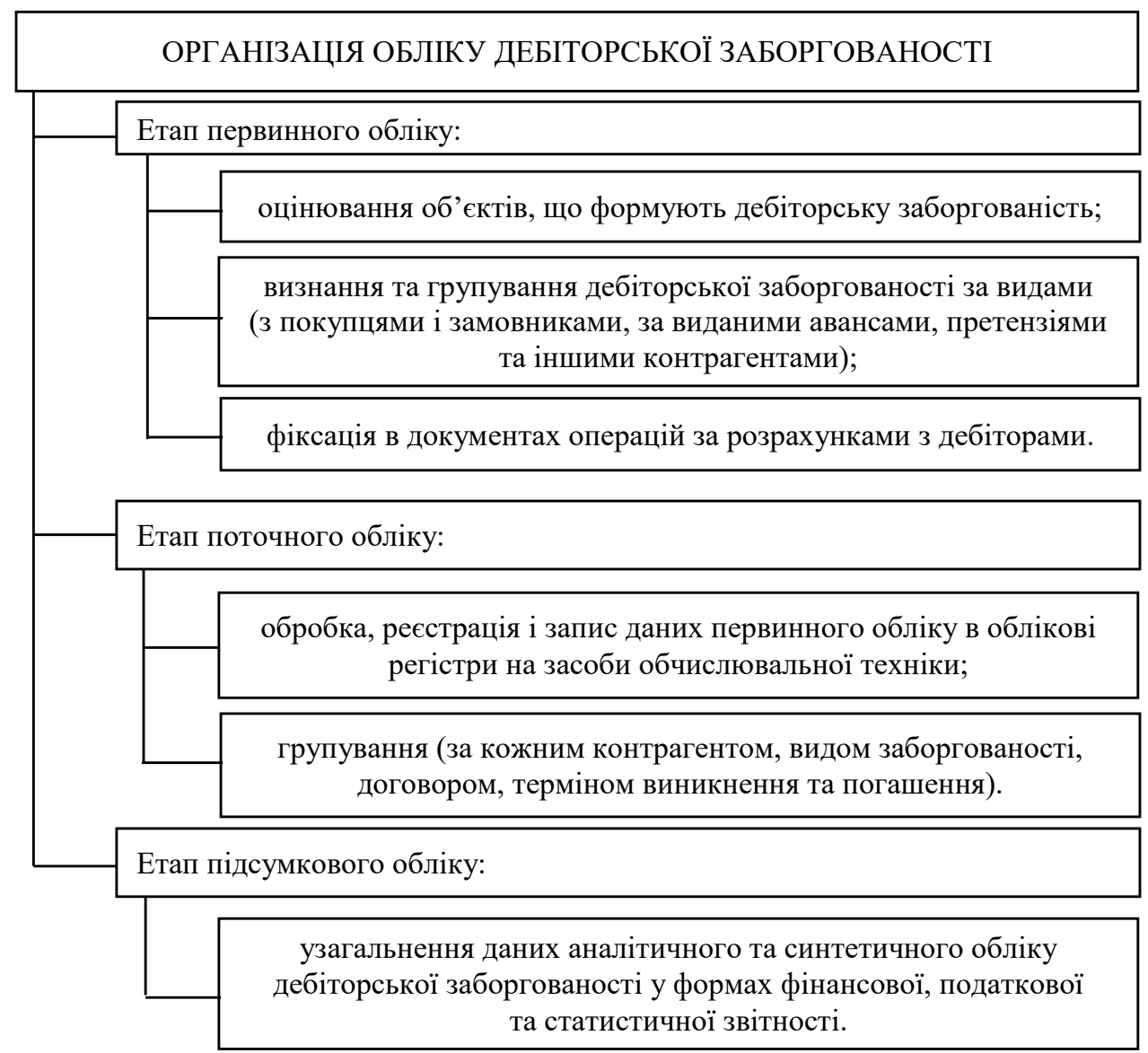

Рис. 3. Етапи організації обліку дебіторської заборгованості на підприемстві Джерело : розроблено авторами за даними [8-10] 
Ефективне управління організацією обліку дебіторської заборгованості складається із умов, правил та процедур, і є однією із ключових потреб у виробничо-господарській діяльності кожного суб'єкта підприємництва, задля виконання поставлених цілей і завдань. 3 метою покращення фрінансовоекономічного стану та досягнення запланованих результатів господарювання, процес обліку дебіторської заборгованості на підприемствах повинен складатись з окремих етапів (рис. 3), дотримуючись яких підприємство матиме можливість едективно та раціонально забезпечувати процес управління дебіторською заборгованістю.

Недосконалість організації обліку дебіторської заборгованості суб’ектів підприемництва призводить до збільшення її суми, втрати змісту облікової інформації, викривлення сутності трактування, зниження достовірності даних бухгалтерського обліку, що має негативний вплив на процес управління нею і фрункціонування підприемства в цілому.

Серед основних проблем організащії обліку дебіторської заборгованості є недосконалий відбір потенційних покупців і замовників. Саме удосконалення системи відбору таких суб'єктів, надасть змогу здійснювати попередню перевірку і ощінку контрагентів щодо можливості своєчасного погашення ними заборгованості і відсутності прострочених платежів, тобто наявність хорошої кредитної історії.

Облік дебіторської заборгованості у межах підприемства здійснюеться 3 моменту складання і підписання договору, де зазначаються суть та умови угоди, обов'язки сторін щодо виконання умов домовленості та відповідальність сторін у разі порушення таких зобов'язань. Для покращення організащї роботи з договорами на належному рівні слід розробити і зазначити додаткові умови щодо надання товарного кредиту, а саме :

- можливість надання знижки контрагенту при здійсненні довгострокової оплати;
- можливість здійснення альтернативної оплати у негрошовій формі (цінні папери) або бартер.

Застосування цих умов у договорі в перспективі призведе до зростання продажів та прискорення оборотності капіталу підприемства.

Необхідною умовою достовірного відображення стану розрахунків 3 дебіторами $є$ резерв сумнівних боргів [11-12], який згідно П(С)БО 10 «Дебіторська заборгованість має створюватися для визначення суми чистої реалізаційної вартості поточної дебіторської заборгованості за товари, роботи, послуги [1].

Однак, у більшості підприемств облік на рахунку 38 «Резерв сумнівних боргів» проводиться, проте сам резерв не створюеться чи розраховується досить приблизно. Це призводить до зростання ризиків щодо понесення значних збитків у разі непогашення заборгованості вчасно, які б зі створеним резервом були б не на стільки вагомими. Таким чином, підприемствам доцільно створити резерв сумнівних боргів, щоб уникнути втрат від оподаткування та розробити порядок його визначення в обліковій політищі.

Висновки і пропозиції. Облік дебіторської заборгованості підприемства потребує значної уваги, що спричинено систематичними затримками взаємних розрахунків і призводить до погіршення фінансового стану та виробничо-господарської діяльності підприємства в цілому. Правильно організований облік дебіторської заборгованості надасть можливість заздалегідь передбачити та не допустити збільшення дебіторської заборгованості, уникнути ризиків виникнення неплатежів та зменшити ймовірність виникнення безнадійної заборгованості. Введення у виробничо-господарську діяльність підприємства рекомендацій щодо вдосконалення організації обліку дебіторської заборгованості, створить умови для швидкого зростання бізнесу і збільшення фінансових можливостей підприемства.

\section{Список літератури:}

1. П(С)БО 10 «Дебіторська заборгованісты». Офіційний сайт Верховної Ради України. URL: https://zakon.rada.gov.ua/ laws/show/z0725-99 (дата звернення: 20.11.2020).

2. Дубровська Є.В. Управління дебіторською заборгованістю підприемств вантажного автотранспорту : автореф. дис. ... канд. екон. наук : спец. 08.00.04 «Економіка та управління підприемствами»; Укр. держ. акад. залізн. трансп. Харків, 2010. 19 с.

3. Белозерцев В. Щодо товарного кредиту та дебіторської заборгованості на підприемстві. Eконоліст. № 11. 2009. C. 23-28.

4. Лищенко О.Г., Бескота Г.М. Аналіз дебіторської заборгованості в системі управління підприемством. Держава і регіони. 2009. № 1. С. 114-117.

5. Райзберг Б.А., Лозовский Л.Ш., Стародубцева Е.Б. Современный экономический словарь. 5-е изд. Москва : ИНФРА-М, 2007. 495 с.

6. Котляр М.Л. Управління дебіторською заборгованістю як важливий чинник підвищення фрінансової стійкості підприемств. Вісник Київького національного університету імені Тараса Шевченка. Серія "Економіка". 2004. № 70. C. 47-49.

7. Волостникова А.Ю. Проблемы учетно-аналитического обеспечения дебиторской и кредиторской задолжености предприятия : авторефр. дис. ... канд. эконом. наук : спец. 08.00.12 «Бухгалтерский учет, статистика». Москва, 2009. 22 с.

8. Кундря-Висоцька О.П., Москаленко О.В., Сулима М.О. Організація бухгалтерського обліку : навч. посібник. Київ : УБС НБУ, 2015. 298 с.

9. Організація бухгалтерського обліку : навчальний посібник / За ред. В.С. Леня. Київ : Центр навчальної літератури, 2006. 696 с.

10. Закревська О.Ю. Організація бухгалтерського обліку поточної дебіторської заборгованості підприемства торгівлі. Причорнолорські економічні студї. 2017. Вип. 20. С. 103-106.

11. Васільева Л.М., Трайно О.В. Організація обліку дебіторської заборгованості та шляхи ії удосконалення. Молодий вчений. 2017. № 10(50). С. 820-823.

12. Сидоренко О.О. Визнання, класифікація та окремі аспекти обліку дебіторської заборгованості у суб'єктів господарювання. Інфбраструктура ринку. 2019. Вип. 32. С. 449-456. 


\section{References:}

1. $\mathrm{P}(\mathrm{S}) \mathrm{BO} 10$ «Debitorska zaborhovanist» [Accounting Standard 10 "Debt receivable"], no. 237 (25 October 1999$).$ Available at: https://zakon.rada.gov.ua/laws/show/z0725-99 (accessed 20 November 2020).

2. Dubrovska Ye.V. (2010) Upravlinnia debitorskoiu zaborhovanistiu pidpryiemstv vantazhnoho avtotransportu [The accounts receivable management of freight transport enterprises] (PhD Thesis), Kharkiv: Druk.

3. Bielozertsev V. (2009) Shchodo tovarnoho kredytu ta debitorskoi zaborhovanosti na pidpryiemstvi [Rade credit and accounts receivable in the enterprise]. Ekonomist, vol. 11, pp. 23-28.

4. Lyshchenko O.H., Beskota H.M. (2009) Analiz debitorskoi zaborhovanosti v systemi upravlinnia pidpryiemstvom [Analysis of receivables in the enterprise management system]. State and regions, no. 1, pp. 114-117.

5. Raizberh B.A., Lozovskyi L.Sh., Starodubtseva E.B. (2007) Sovremennyi ekonomycheskyi slovar [Modern Economic Dictionary]. Moscow: YNFRA-M. (in Russian)

6. Kotliar M.L. (2004) Upravlinnia debitorskoiu zaborhovanistiu yak vazhlyvyi chynnyk pidvyshchennia finansovoi stiikosti pidpryiemstv [Accounts receivable management as an important factor in increasing the financial stability of enterprises]. Bulletin of Taras Shevchenko National University of Kyiv. Economics, no. 70, pp. 47-49.

7. Volostnykova A.Iu. (2009) Problemy uchetno-analytycheskoho obespechenyia debytorskoi y kredytorskoi zadolzhenosty predpryiatyia [The problems of accounting and analytical support of receivables and payables of the enterprise] (PhD Thesis), Moscow: NGY.

8. Kundria-Vysotska O.P., Moskalenko O.V., Sulyma M.O. (2015) Orhanizatsiia bukhhalterskoho obliku [Organization of accounting]. Kyiv: UBS NBU. (in Ukrainian)

9. Len V.S. (2006) Orhanizatsiia bukhhalterskoho obliku [Organization of accounting]. Kyiv: Tsentr navchalnoi literatury. (in Ukrainian)

10. Zakrevska O.Iu. (2017) Orhanizatsiia bukhhalterskoho obliku potochnoi debitorskoi zaborhovanosti pidpryiemstva torhivli [The organization of accounting of current receivables of trade enterprises]. Black sea economic studies, vol. 20, pp. 103-106.

11. Vasilieva L.M., Traino A.V. (2017) Orhanizatsiia obliku debitorskoi zaborhovanosti ta shliahy ii udoskonalennia [The organization of accounts receivable and the ways of its improvement]. Young Scientist, no. 10 (50), pp. 820-823.

12. Sidorenko A.A. (2019) Vyznannia, klasyfikatsiia ta okremi aspekty obliku debitorskoi zaborhovanosti u subiektiv gospodariuvannia [Recognition, classification and individual aspects of the accounting of accounts receivable by business subjects]. Market Infrastructure, vol. 32, pp. 449-456. 